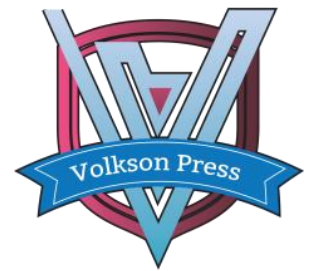

Contents List available at VOLKSON PRESS

Economics \& Management Innovations(EMI)

DOI : http://doi.org/10.26480/icemi.01.2017.174.176

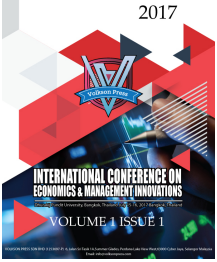

\title{
Stock market response to changes in movies' opening dates ---Based on the Empirical Analysis of China's domestic listed film company
}

\author{
Jinjin Wang ${ }^{*}$ \\ ${ }^{1}$ School of Economics and Management, Jiangsu University of Science and Technology, China *15178594330@163.com \\ This is an open access article distributed under the Creative Commons Attribution License, which permits unrestricted use, distribution, and reproduction in any \\ medium, provided the original work is properly cited.
}

\section{ARTICLE DETAILS}

\section{Article History:}

Received 02 october 2017

Accepted 06 october 2017

Available online 11 october 2017

\section{Keywords:}

Motion pictures Release dates

Event study Stock market

response..

\section{ABSTRACT}

With the rapid development of the Chinese securities market, there is more and more discussion about the change of the public company. We analyze stock market reactions to information about changes in opening dates of movies. The purpose of this paper is to discuss the explanatory power of the change announcement information to the stock market reaction. Empirical results show that China's film industry is different from the American film industry's interpretation of stock performance in terms of changing public information. China's stock market is not sensitive to film production cost, and there is no significant market reaction.

\section{Introduction}

This article studies the stock market reaction to announcements about changes in movies' opening dates. The unique data and setting allow us to gauge the market reaction to specific projects. Since the establishment of cinema line system in 2002, the Chinese film industry has entered the fast lane of development. According to the film bureau of the state administration of radio, film and television, a piece of a box-office gross that grew $39.9 \%$ to 45.712 billion yuan in 2016 , compared with the box office figures of 2002, the increase was 49.6 times. China's film market is the second-largest movie market after North America.

We present empirical finding. The result shows that the magnitude of the stock market response is significantly associated with the size of the movie, as measured by its box office revenues and market capitalization. However, measures of the movies' subsequent financial success, such as production costs (film genre, film rating, star power), are unrelated to the market reaction.

Our findings contribute to several areas of research. Our first finding is similar in spirit to a large literature in finance, which reports negative market reaction to a wide array of corporate changes. For example, Palmrose (2004) find that the market reaction to earnings restatements, even ones that appear to improve transparency, is uniformly negative [1], and Graham (2008) find that the reaction of the bond market to earning restatements is always negative [2]. Thus, similar to what we document, the market seems to be skeptical of any alteration to previously provided information. Liu tingli ( 2009 ) find that board chairman turnover transmits adverse information to capital market and further study also confirms that earnings quality decline always accompany board chairman turnover that means board chairman turnover is an important opportunity to manipulating earnings, which can be identified by market , inducing significant negative cumulate abnormal returns [3] · Liu yuanyuan and Wang shaoan(2013)find that annual reports of listed companies changes announcement on the whole, some negative influence on the value of the company, but the change of different nature, different time span announcement reaction have obvious difference [4]. Methodologically, this study is similar in its approach to two other articles that apply event study analysis to different types of events also associated with motion pictures (Joshi and Hanssens 2009) [5].

\section{Literature review}

Some foreign researchers have studied the overall performance of companies' share prices before and after the announcement. For example, Anderson and Yohn. (2002) examine the effect of the restatement on earnings response coefficients, and find that the market reacts less to earnings after a restatement than to earnings prior to a restatement [6]. Palmrose. (2004) find that the market reaction to earnings restatements, even ones that appear to improve transparency, is uniformly negative [1], and Graham. (2008) find that the reaction of the bond market to earning restatements is always negative [2]. Thus, similar to what we document, the market seems to be skeptical of any alteration to previously provided information. Einav and Ravid (2009) find that the market reaction is greater for movies with higher production costs, but is unrelated to subsequent box office revenues [7]

There are also big differences between China and developed countries, which are represented by the United States. As a result, we cannot copy foreign studies from the domestic market, and the domestic market should be analyzed in a specific way. ZhouYang and Li Ruoshan (2007) find that the restatement of good news and bad message types will have a significant positive and negative impact [8]. Methodologically, this study is similar in its approach to two other recent articles that apply event study analysis to different types of events also associated with motion pictures. Liu yuanyuan, Wang shaoan (2013) find that changes in the annual report of the listed company have a negative effect on the value of the company in general, but the market reactions of different properties, different timescales, were significantly different [4]. Hu Xiaoli , Han Ran(2016)find that the relevance of the stock market and the film market, and established a related econometric model to study the correlation of stock and film market in China [9] - Above the domestic and foreign scholars for the relationship between the influencing factors of stock market and film market research, provides a solid theoretical foundation for this study.

\section{Date and empirical strategy}

\subsection{Sample selection and data source}

We collected data on announcements of changes in release dates of movies. The original dataset contained 2048 such events covering the period from 2008 to 2015. We use the date of the published report in which the change is made as the date of the event. Since some movies had several release time changes in our dataset, we have 1828 unique movies produced by 32 studios. In order to use standard event study methodology, we must consider only announcements by studios owned by 
publicly traded firms. In particular, daily return data for the stock of the firm must be available from Wind for a sufficient period around the event date. Dropping events with insufficient stock data left us with 221 events. Our final dataset contains 186 changes concerning 221 movies distributed by 12 different studios. Release dates are obtained from Douban Movie, Mtime Movie and China Competition Information. The empirical part of this study we match the events with companies' financial information (financial variables from Wind Economic Database). All the financial variables are adjusted for inflation. These variables are summarized in Table 1.

Table1 Summary statistics of financial data

\begin{tabular}{|c|c|c|c|c|c|}
\hline $\begin{array}{l}\text { Firm } \\
\text { code })\end{array}$ & $\begin{array}{l}\text { Market } \\
\text { capitalizatio } \\
\mathrm{n}\end{array}$ & $\begin{array}{l}\text { Net } \\
\text { profit } \\
\text { s }\end{array}$ & $\begin{array}{l}\text { Gross } \\
\text { profit } \\
\text { s }\end{array}$ & $\begin{array}{l}\text { total } \\
\text { assets }\end{array}$ & $\begin{array}{l}\text { Long } \\
\text {-term } \\
\text { debt }\end{array}$ \\
\hline $\begin{array}{ll}\text { CHINA } & \text { FILM } \\
600977 & \end{array}$ & 510.25 & 6.05 & 8.08 & $\begin{array}{l}109.6 \\
9\end{array}$ & 49.95 \\
\hline $\begin{array}{lr}\text { WAN } & \text { DA } \\
\text { CINEMA } & \text { LINE } \\
002739 & \end{array}$ & 793.40 & 8.05 & 10.25 & $\begin{array}{l}158.6 \\
8\end{array}$ & 60.84 \\
\hline $\begin{array}{l}\text { SHANGHAI } \\
\text { FILM } \\
601595\end{array}$ & 149.18 & 1.23 & 1.38 & 17.02 & 7.44 \\
\hline $\begin{array}{l}\text { TALENT } \\
\text { TELEVISION \& } \\
\text { FILM } 300426\end{array}$ & 108.16 & 0.57 & 0.52 & 20.28 & 10.92 \\
\hline $\begin{array}{lr}\text { HUACE } & \text { FILM } \\
\text { and } & \text { TV } \\
300133 & \end{array}$ & 238.41 & 2.71 & 3.32 & 94.96 & 32.81 \\
\hline $\begin{array}{l}\text { HUAYI } \\
\text { BROTHERS } \\
\text { MEDIA } \\
300027\end{array}$ & 344.82 & 3.03 & 4.17 & $\begin{array}{l}188.1 \\
8\end{array}$ & 85.01 \\
\hline $\begin{array}{l}\text { BEIJING } \\
\text { ENLINGT } \\
\text { MEDIA } \\
300251\end{array}$ & 318.59 & 3.21 & 3.41 & 87.21 & 16.09 \\
\hline $\begin{array}{l}\text { ORIENTAL } \\
\text { TIMES MEDIA } \\
002175\end{array}$ & 133.34 & 0.22 & 0.26 & 28.65 & 13.09 \\
\hline $\begin{array}{l}\text { WUHAN DDMC } \\
\text { CULTURE } \\
600136\end{array}$ & 93.59 & 0.20 & 0.36 & 31.25 & 7.95 \\
\hline $\begin{array}{l}\text { ORANGE SKY G } \\
\mathrm{H} \quad \mathrm{HK} 1132\end{array}$ & 8.96 & -0.35 & -0.20 & 25.09 & 11.35 \\
\hline $\begin{array}{l}\text { SMI } \\
\text { CORPORATIO } \\
\mathrm{N} \quad \text { HK0198 }\end{array}$ & 87.78 & 2.76 & 3.22 & 89.72 & 44.44 \\
\hline $\begin{array}{l}\text { BONA FILM } \\
\text { GROUP } \\
\text { LIMITED } \\
\text { BONA }\end{array}$ & 50 & 0.05 & 0.17 & 47.71 & 33.71 \\
\hline
\end{tabular}

\subsection{Design of the event study model}

This paper empirically studies the stock price effect of announcements of changes in release dates of movies by using the event study. The finance literature uses "event study" methodology to assess the market valuation of the impact of any corporate event. The idea is first to calculate expected returns for a given company on a given day in the absence of the event and then compute "abnormal returns," that is, returns that are presumably due to the event. In the field of economics and finance, event research is a very important research tool. The goal of the study is to measure the value of a company's stock price to new information. This method is used to study the reasons for the change of the release date of the movie:(1)The announcement of the release date is identifiable ; 2 Changes in the release date may change the distribution of stock returns. To facilitate comparison with prior studies, this study used a time period of 200 days before the event to estimate the expected return as Figure 1.

\section{Figure 1 Estimation and Event Period}

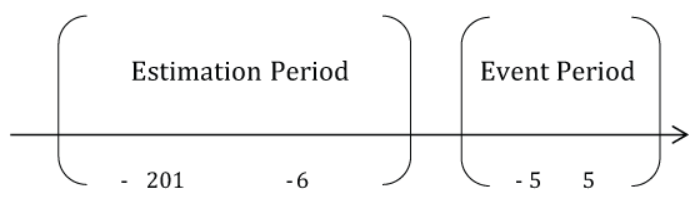

Abnormal returns are unbiased estimates of changes in the market value of the firm during the event period, which reflect the price reaction to the event. The abnormal return for the stock of firm $j$ on event day $t$ is calculated as :

$$
A R_{\mathrm{jt}}=R_{j t}-\left(\alpha_{j}+\beta_{j} R_{m t}\right)
$$

Where

$$
\begin{aligned}
& A R_{\mathrm{jt}}: \text { Abnormal return of } \mathrm{jth} \text { firm for time period } \mathrm{t} ; \\
& R_{\mathrm{jt}}: \text { Actual return of jth firm for time period } \mathrm{t} ; \\
& \alpha_{\mathrm{j}}: \text { Intercept term; } \\
& \beta_{\mathrm{j}}: \text { Systematic risk of } \mathrm{jth} \text { firm, and } \\
& R_{\mathrm{m} t}: \text { Actual return of market for time period } \mathrm{t} .
\end{aligned}
$$

There is another option that we have to select which market index to use for $R_{\mathrm{m} t}$. There are two commonly used market indexes: (1) the equallyweighted index; and (2) the value-weighted index. The equally-weighted index is more likely to detect abnormal security returns. This is due to the fact that the greater degree of correlation between the equally-weighted index and returns; the greater the precision of the estimated parameters, the more easily detectable are the abnormal returns. To test whether abnormal returns over the event period are significantly different from zero, we first compute the standardized abnormal return (SAR) for firm $j$ on event day $t$ as

$$
S A R_{\mathrm{j} t}=A R_{j t} / S D_{j t}
$$

With

$$
S D_{\mathrm{jt}}=\left\{S_{j}^{2} \times\left[1+1 / T\left(R_{m t}-R_{m}\right)^{2} / \sum_{j=-201}^{-6}\left(R_{m t}-R_{m}\right)^{2}\right]\right\}^{0.5}
$$

where

$S_{\mathrm{j}}^{2}$ is the residual variance from the market model over the estimation period, and $R_{\mathrm{m}}$ is the mean return on the market index over the estimation period.

The cumulative standardized abnormal return (CAR) for each firm is computed as

$$
C A R_{\mathrm{j}}=\sum_{t=-5}^{5} S A R_{j t} / \sqrt{2}
$$

Finally, to assess the statistical significance of the average effect of the event on the market value of the $\mathrm{N}$ firms, the Z-statistic is defined as

$$
Z=\sqrt{N} \times A C A R
$$

\begin{tabular}{|c|c|c|c|c|}
\hline Variable & Definition & Min & Max & Mean \\
\hline $\begin{array}{c}\text { film } \\
\text { genres(Drama) }\end{array}$ & $\begin{array}{l}\text { If it's a drama, its value is } \\
1 \text {, otherwise it's } 0\end{array}$ & 0 & 1 & 0.49 \\
\hline film & $\begin{array}{l}\text { If an action movie, its } \\
\text { value is } 1 \text {, otherwise it's } \\
0\end{array}$ & 0 & 1 & 0.12 \\
\hline $\begin{array}{c}\text { film } \\
\text { genres(Love) }\end{array}$ & $\begin{array}{l}\text { If the love movie, its } \\
\text { value is } 1 \text {, otherwise it's } \\
0\end{array}$ & 0 & 1 & 0.20 \\
\hline
\end{tabular}

Where

$$
A C A R=\sum_{j=-5}^{5} C A R_{j} / N
$$

The significance of the abnormal return based on the Z-statistic test allows the researcher to infer that investment announcements have a significant impact on the market value of the firms.

This study gives a description of the dependent variables, and control variables such as Table 2

\section{Table 2 Descriptive Statistics for the Variables}




\begin{tabular}{|c|c|c|c|c|}
\hline $\begin{array}{l}\text { film genres ( } \\
\text { Comedy) }\end{array}$ & $\begin{array}{l}\text { If it's a comedy, it value } \\
\text { is } 1 \text {, otherwise it's } 0\end{array}$ & 0 & 1 & 0.26 \\
\hline $\begin{array}{l}\text { film genres ( } \\
\text { Fantasy) }\end{array}$ & $\begin{array}{l}\text { If it's a fantasy, it's going } \\
\text { to be } 1 \text {, otherwise it's } 0\end{array}$ & 0 & 1 & 0.06 \\
\hline $\begin{array}{l}\text { film genres } \\
\text { Thriller })\end{array}$ & $\begin{array}{l}\text { If it's a thriller, its value } \\
\text { is } 1 \text {, otherwise it's } 0\end{array}$ & 0 & 1 & 0.04 \\
\hline Rating & $\begin{array}{l}\text { The average of Douban } \\
\text { films and Mtime films } \\
\text { rating }\end{array}$ & 2.2 & 9 & 4 \\
\hline Star power & $\begin{array}{l}\text { The average } \\
\text { performance of an actor } \\
\text { in nearly three years }\end{array}$ & 8 & 30 & 16.73 \\
\hline Film production & $\begin{array}{l}\text { Film production and } \\
\text { distribution cost }(10,000 \\
\text { yuan) take logs }\end{array}$ & 2.3 & 3 & 2.65 \\
\hline CAR & $\begin{array}{l}\text { Summarize the daily } \\
\text { excess earnings of a } \\
\text { certain event }\end{array}$ & $\overline{-}$ & 0.09 & $\overline{-}-$ \\
\hline
\end{tabular}

\subsection{Empirical research}

This study examines whether the stock market will respond differently depending on the information contained in the announcement. Finally, a regression analysis method is used to analyze the problem of the explanation of the accumulated excess yield of stocks. We did the test of the correlation between film production cost, film genre, rating, star power and cumulative abnormal return in the three stages of $\mathrm{T}(-1,1), \mathrm{T}(-$ $2,2)$ and $\mathrm{T}(-5,5)$ as Table 3.

\section{Table 3 Cumulative abnormal return, by type of event}

\begin{tabular}{|c|c|c|c|c|}
\hline & & $\begin{array}{l}\text { CAR(- } \\
1, \quad 1)\end{array}$ & $\begin{array}{l}\text { CAR(- } \\
2, \quad 2)\end{array}$ & $\begin{array}{l}\text { CAR(- } \\
5, \quad 5)\end{array}$ \\
\hline \multirow[t]{3}{*}{$\begin{array}{l}\text { Production } \\
\text { cost }\end{array}$} & correlation & 0.006 & 0.004 & 0.004 \\
\hline & Sig. (1-tailed) & 0.983 & 0.574 & 0.523 \\
\hline & No. of obs. & 112 & 112 & 112 \\
\hline \multirow[t]{3}{*}{ Rating } & correlation coefficient & 0.000 & 0.000 & 0.000 \\
\hline & Sig. (1-tailed) & 0.821 & 0.757 & 0.741 \\
\hline & No. of obs. & 151 & 151 & 140 \\
\hline \multirow[t]{3}{*}{ Star power } & correlation coefficient & 0.000 & 0.000 & 0.000 \\
\hline & Sig. (1-tailed) & 0.973 & 0.595 & 0.261 \\
\hline & No. of obs. & 185 & 185 & 173 \\
\hline \multirow[t]{3}{*}{ Film genre } & correlation coefficient & 0.000 & 0.000 & 0.000 \\
\hline & Sig. (1-tailed) & 0.108 & 0.339 & 0.451 \\
\hline & No. of obs. & 185 & 185 & 173 \\
\hline
\end{tabular}

According to the table 3 , During $\mathrm{T}(-1,1), \mathrm{T}(-2,2)$ and $\mathrm{T}(-5,5)$, the cost of production, film genre, film rating, star power and the accumulated excess returns of the company's stock are irrelevant. The results show that investors are not sensitive to the production cost of making a change announcement, and the stock market has no significant reaction to the information, whether there are some changes before the announcement, or after the release.

\section{Conclusions}

According to the result, the cost of production, film genre, film rating, star power and the accumulated excess returns of the company's stock are irrelevant. It is proved that the stock market in our country cannot identify these factors in the change announcement. In future studies, further analysis of possible influences should be further analyzed. For example, film schedule, box office revenues, market capitalization and heat network. To make suggestions for the next investment in the film and make the biggest gains for movie planners and investors, we will add box office revenues and market capitalization to the event study model. Our findings can provide a basis for later work, and this study provides stock market reactions to information about changes in opening dates of movies as well as further insight into the study of the change announcement on organizational performance.

\section{References}

[1]Palmrose, Z., Richardson, V. J., \& Scholz, S. Determinants of market reactions to restatement announcements [J]. Journal of Accounting and Economics, 2004(37): 59-89.

[2]Graham, J. R., Li, S., \& Qiu, J. Corporate misreporting and bank loan contracting [J]. Journal of Financial Economics, 2008(89): 44-61.

[3]Liu tingli. The effect of Board Chairman Turnover on Earnings Quality--The Experimental Result of Event Study [J]. Scientific Decision Making, 2009(2): 21-28

[4]Liu Yuanyuan, Wang Shaoan. Study on Market Reaction of Listed Companies Correcting Announcement [J]. Macroeconomic Research, 2013 (9): 98-105.

[5]Joshi, A.M. \& Hanssens, D.M. Movie advertising and the stock market valuation of studios: A case of gr eat expectations [J] .Marketing Science, 2009, 28(7): 239-250.

[6]Anderson, K.L. \& Yohn, T.L. The effect of $10 \mathrm{~K}$ restatements on firm value, information asymmetries, and investors' reliance on earnings [J]. Ssrn electronic journal, 2002, 9(2): 337-356.

[7]L Einav, SA Ravid. Stock market response to changes in movies'opening dates [J].Journal of cultrual economics, 2009, 33(4): 311-319.

[8]Zhou Yang, LI Ruoshan. Annual reports of listed companies "patch" features and market reaction [J]. Auditing Research, 2007 (4): 69-75.

[9]Hu Xiaoli , Han Ran. Research on the Relevance of the Stock Market and Film Market in China [J]. Academic Exchange, 2016(4): 36-38. 